\begin{tabular}{|c|c|c|}
\hline & Int.J.Curr.Microbiol.App.Sci (2021) 10(10): 47-49 & \\
\hline EXCELLENT & $\begin{array}{l}\text { International Journal of Current Microbiology and Applied Sciences } \\
\text { ISSN: 2319-7706 Volume } \mathbf{1 0} \text { Number } \mathbf{1 0}(\mathbf{2 0 2 1 )} \\
\text { Journal homepage: http://www.ijcmas.com }\end{array}$ & 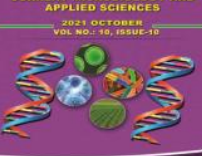 \\
\hline PUBLISHERS & & wwwijicmas.com \\
\hline
\end{tabular}

\title{
Effect of Different Sowing Dates on Grain Yield and Incidence of Lentil Wilt Caused by Fusarium oxysporum f. sp. lentis
}

\author{
Sakshi Sharma ${ }^{* *}$, B. K. Sharma ${ }^{2}$ and D. K. Banyal ${ }^{1}$ \\ ${ }^{1}$ Department of Plant Pathology, CSK HPKV, Palampur, India \\ ${ }^{2}$ CSK HPKV, Research Sub Station Akrot, India \\ *Corresponding author
}

Keywords

Lentil, wilt,

Fusarium

oxysporum f.sp.

lentis

Article Info

Accepted:

05 September 2021

Available Online:

10 October 2021
Wilt of lentil, caused by Fusarium oxysporum f.sp. lentis is a serious disease and plays major role in reducing lentil yield in India and Abroad. There are many factors which influence disease development. The present studies were, therefore, undertaken to study the effect of different dates of sowing on disease incidence and grain yield. The crop was sown on four dates during rabi 2019-20 and 2020-21 i.e. $15^{\text {th }}$ October, $30^{\text {th }}$ October, $15^{\text {th }}$ November and $30^{\text {th }}$ November. The disease incidence was maximum (10.74 per cent) in early sown crop as compared to the late sown crop (3.32 per cent).The grain yield was maximum at third date of sowing i.e. $15^{\text {th }}$ November (10.94 q/ha).

\section{Introduction}

Pulses constitute an important part of human food and are very rich in protein content and quality. The protein content ranges from 17-24 percent in pulses which is 2-3 times more than cereals. Pulses also play an important role in the food and farming economy of our country (Garkoti et al., 2013). Lentil (Lens culinaris Medikus) is considered as the oldest pulse crop, maybe domesticated in habitation up to 13,000 years BC. It is mainly grown in India, Egypt, Greece, Bangladesh, Pakistan, Italy, countries in the Mediterranean region and
North America. Lentil is highly proteinaceous crop as it contains 25 per cent of protein and is suitable for cultivation under varied climatic conditions. It improves the soil fertility in the areas where other legumes are not grown. Lentil provides affordable protein; hence it is also known as poor man's meat. Fusarium wilt caused by Fusarium oxysporum f. sp. lentis is predominant in the lentil growing areas worldwide. The pathogen is soil and seed borne. It colonizes and completely blocks the xylem vessels leading to wilting of plant. The disease can occur at any stage of the crop starting from seedling stage however, the yield 
losses depend upon the stage at which the plant wilts. Time of sowing and temporal factors also affects the disease incidence. Hence the current study was conducted to see effect of different dates of sowing on lentil wilt incidence and grain yield

\section{Materials and Methods}

The effect of four dates of sowing on the development of lentil wilt was studied by conducting an experiment under field conditions at CSK HPKV Research Sub Station, Akrot (Una) in a Randomized Block Design (RBD). Lentil variety HPL-5 was used during two seasons i.e. rabi 2019-20 and 2020-21 on four different dates, i.e. $15^{\text {th }}$ October, $30^{\text {th }}$ October, $15^{\text {th }}$ November and $30^{\text {th }}$ November. The wilt incidence was recorded at weekly intervals starting from first appearance of the disease.

\section{Results and Discussion}

The pooled data presented in Table 1 reveals that disease incidence was more in crop sown on $15^{\text {th }}$ October (10.74 per cent) followed by $30^{\text {th }}$ October $(8.12$ per cent $), 15^{\text {th }}$ November (5.82 per cent) and $30^{\text {th }}$ November (3.32 per cent) during rabi 2019-20 and 2020-21. The grain yield was maximum (10.94 q/ha) on third date of sowing ( $15^{\text {th }}$ Nov.) followed by second date of sowing i.e. $30^{\text {th }}$ Oct. $(9.55 \mathrm{q} / \mathrm{ha})$ and first date of sowing i.e. $15^{\text {th }}$ Oct. $(8.68$ $\mathrm{q} / \mathrm{ha})$. As has been observed during the present studies, Kannaiyan and Nene (1975) reported that among 5 dates of sowing at 15 days intervals starting from 15 October till15 December, incidence of wilt was lower in later sown crops. Mittal (1997) reported that the sole crop of lentil variety VL Massor-1 was more susceptible to disease i.e. wilt, rust, downy mildew, root rot etc. than the crop mixed with wheat variety VL 616 and the disease incidence declined gradually with the sowing dates.

The present observations of low wilt incidence in late planting were supported by the results of Ahmed et al., (1998) who reported the effect of different control options i.e. sowing dates, host plant resistance and fungicide seed treatment on wilt disease and yield parameters.

Table.1 Effect of date of sowing on lentil wilt and grain yield under field conditions

\begin{tabular}{|c|c|c|c|c|c|c|}
\hline \multirow[t]{2}{*}{ Sowing date } & \multicolumn{2}{|c|}{ Season (Rabi 2019-20) } & \multicolumn{2}{|c|}{ Season (Rabi 2020-21) } & \multicolumn{2}{|c|}{$\begin{array}{c}\text { Pooled Average } \\
(2019-20 \text { \& 2020-21) }\end{array}$} \\
\hline & $\begin{array}{c}\text { wilt incidence } \\
(\%)\end{array}$ & $\begin{array}{c}\text { grain yield } \\
\text { (q.ha) }\end{array}$ & $\begin{array}{c}\text { wilt } \\
\text { incidence } \\
(\%)\end{array}$ & $\begin{array}{c}\text { grain yield } \\
\text { (q.ha) }\end{array}$ & $\begin{array}{c}\text { wilt } \\
\text { incidence } \\
(\%)\end{array}$ & $\begin{array}{c}\text { Grain yield } \\
\text { (q/ha) }\end{array}$ \\
\hline 15th Oct. & 11.32 & 8.38 & 10.16 & 8.99 & 10.74 & 8.68 \\
\hline 30th Oct. & 8.28 & 9.38 & 7.96 & 9.72 & 8.12 & 9.55 \\
\hline 15th Nov. & 6.00 & 10.82 & 5.64 & 11.06 & 5.82 & 10.94 \\
\hline 30th Nov. & 3.68 & 8.49 & 2.96 & 8.10 & 3.32 & 8.29 \\
\hline $\operatorname{CD}(p=0.05)$ & 0.65 & $\mathbf{0 . 5 3}$ & 0.83 & 0.34 & 0.74 & 0.43 \\
\hline
\end{tabular}

They found that percent terminal wilt incidence and areas under the disease progress curve were the lowest during November plantings for all genotypes. Similarly, Nashwa and Monaster (2012) reported that late sowing i.e. (November or December) and sowing depth of $2 \mathrm{~cm}$ were the best for the reduction of lentil wilt. 


\section{References}

Ahmed S., Akem C., Bayaa B. and Erskine W. 1998. Integrating host resistance with planting date and fungicide seed treatment to manage Fusarium wilt and increase lentil yields. International journal of Pest management 48:121125.

Anonymous. Food and Agriculture Organization of the United States. http:/www.fao.org/faostat/en/ (2019).

Anonymous. 2017. Genetic variation and disease resistance in lentil (Lens culinaris). https://www. Researchgate.net/publication/3131218 19.

Garkoti A, Kumar S, Singh M and Singh V.
2013. Epidemiology and disease management-A Review. AGRIWAYS 1:62-64.

Kannaiyan J. and Nene Y. L. 1975. Note on the effect of sowing dates on the reaction of twelve lentil varieties to wilt disease. Madras Agricultural journal 62: 240-242.

Mittal R K. 1997. Effect of sowing dates and disease development in lentil as sole and mixed crop with wheat. Journal of Mycology and Plant Pathology 2: 203209.

Nashwa M. A. Sallam and Monaster F. A. Monaim. 2012. Influence of some Agricultural practices on suppression of lentil wilt disease. Plant Pathology journal. 11: 32-37.

\section{How to cite this article:}

Sakshi Sharma, B. K. Sharma and Banyal, D. K. 2021. Effect of Different Sowing Dates on Grain Yield and Incidence of Lentil Wilt Caused by Fusarium oxysporum f. sp. lentis. Int.J.Curr.Microbiol.App.Sci. 10(10): 47-49. doi: https://doi.org/10.20546/ijcmas.2021.1010.007 